\title{
Penggunaan Metode Eksperimen Dengan Pembelajaran Kooperatif Untuk Meningkatkan Minat Dan Hasil Belajar Pada Pokok Bahasan Peluang Di Kelas XI. IPA 2 SMAN 5 Muaro Jambi
}

\author{
Agustarizal \\ Sekolah Menengah Atas Negeri 12 Kota Jambi, Indonesia
}

Abstract Most of the student difficulties in learning math because this subject demands students for logical thinking and understanding the concepts relate numbers and imajiner. This study intends to improve students understanding of math concepts in opportunity topic in order to increase students' learning achievement, and to create a fun learning in math.

This study employs the classroom action research in two cycles in IPA X2 in SMAN 5 Muaro Jambi. This study found that: 1) the student results learning is increasing, 2) students are actively in learning and highly participate in lerning

Keywords: students' learning achievement, math subject, opportunity topic.

\section{Pendahuluan}

Berdasarkan pengamatan guru-guru di SMA Negeri 5 Muaro Jambi khususnya guru bidang studi matematika, hampir sebagian besar siswa mengalami kesulitan dalam belajar pada materi pembelajaran yang membutuhkan pemahaman, daya nalar, dan daya fikir yang cukup tinggi, seperti halnya pada materi peluang. Pada peluang dituntut untuk memahami konsep, penalaran logika yang yang berhubungan dengan bilangan dan daya khayal yang cukup tinggi. Hal inilah yang menyebabkan minat belajar matematika rendah, selain itu tidak dipungkiri pelajaran matematika merupakan pelajaran yang 
kurang disenangi oleh siswa yang ditunjukkan oleh sikap sebagian besar siswa phobia terhadap pelajaran matematika, akibatnya minat belajar terhadap matematika menjadi rendah.

Pada materi peluang, siswa mengalami kesulitan untuk membayangkan kemungkinan suatu kejadian, mengingat pembelajarn yang terjadi di sekolah tidak digunakannya alat peraga, tetapi hanya menggunakan daya khayal dan daya ingat tentang kemungkinan suatu kejadian, sehingga menyebabkan minat belajar rendah yang mengakibatkan hasil belajar menjadi rendah pula.

Berdasarkan latar belakang masalah tersebut, penulis merumuskan judul penelitian "Penggunaan Metode Eksperimen dengan Pembelajaran Kooperatif untuk Meningkatkan Minat dan Hasil Belajar pada Pokok Bahasan Peluang dikelas XI IPA.2 SMA Negeri 5 Muaro Jambi".

\section{Landasan Teori}

\section{Metode Eksperimen}

Metode menurut (Ma'mur dan Asmani, 2011, p.45) adalah cara evaluasi, analisis dan seleksi dari berbagai alternatif, cara atau teknik atau dengan kata lain metode dapat digambarkan sebagai langkahlangkah untuk melakukan kegiatan penelitian. Eksperimen adalah kegiatan melakukan percobaan dimana terdapat capur tangan atau intervensi peneliti yang melebihi persyaratan untuk pengukuran. Menurut (Krismanto, 2003, p.89) bahwa eksperimen/kerja praktik adalah yang dikenal hands on mathematics (matematika dengan 
sentuhan tangan atau mengutak-atik obyek dengan tangan). Hands on mathematics ini merupakan kegiatan " pengalaman belajar" dalam rangka penemuan konsep atau prinsip matematika melalui kegiatan eksplorasi, investigasi, dan konklusi yang melibatkan aktivitas fisik, mental dan emosional. Jadi dapat disimpulkan bahwa metode eksperimen adalah suatu cara atau langkah-langkah untuk melakukan kegiatan penelitian atau percobaan dimana terdapat campur tangan yang melibatkan aktivitas fisik, mental dan emosional dalam rangka menemukan konsep atau prinsip matematika.

\section{Model Pembelajaran Kooperatif}

Pembelajaran kooperatif atau cooperatif learning mengacu pada metode pengajaran dimana siswa bekekrja sama dalam kelompokkelompok kecil yang saling membantu dalam kegiatan pembelajaran. Kegiatan utama kelompok-kelompok siswa ini adalah mendiskusikkan tugas-tugas matematika yang diberikan gurunya dan saling membantu menyelesaikan tugas dalam memecahkan masalah.

Pembelajaran kooperatif membantu siswa untuk aktif berinteraksi ssecara optimal antara seluruh komponen dalam kegiatan pembelajaran. (Krismanto, 2003, p.67) faktor yang memungkinkan terjadinya interaksi yang terjadi antara guru dan siswa berkaitan atau bersumber pada bervariasinya berbagai situasi belajar mangajar yang dikembangkan oleh guru. 
Dengan demikian jika kedua faktor digabungkan maka akan diperoleh optimalisasi siswa aktif dalam pembelajaran, yang akhirnya dapat meningkatkan minat dan hasil belajar siswa.

\section{Minat dan Hasil Belajar}

Mc.Cicland dan Akitson dalam (Wiryamin,1989, p.98) berpendapat bahwa siswa yang minat belajarnya tinggi untuk mencapai prestasi dalam merespon dan menantang lebih baik terhadap tugastugasyang diberikan guru, nilai yang baik memberikan umpan balik yang jitu dan benar.

Dalam (Karti Soeharto, dkk, 1995, p.76) belajar adalah suatu proses yang komplek, rumit dan unik, karena memiliki ciriciri/karakteristik tertentu yang berbeda antara sibelajar yang satu dengan sibelajar yang lain. Artinya belajar akan terjadi karena individu itu sendiri melakukannya.

\section{Peluang}

Terdengar ditelinga kita kata-kata peluang sudah tidak asing lagi, karena setiap hari tanpa di sadari kita berhubungan dengan peluang. Peluang adalah kesempatan untuk memperoleh sesuatu sesuai dengan keinginan. Sehingga tidak timbul kesenjangan antara harapan dengan kenyataan.

Pada penelitian tindakan kelas ini materi yang akan dipelajari adalah :

Peluang suatu kejadian

1. Pengertian titik sampel dan ruang sampel 
Titik sampel adalah kejadian khusus atau suatu unsur dari ruang sampel

Ruang sampel adalah himpunan semua titik sampel atau himpunan semua hasilyang mungkin dari suatu percobaan.

2. Peluang suatu kejadian

Jika pada suatu percobaan terdapat $\mathrm{n}$ hasil yang mungkin dan masing-masing berkesempatan sama untuk muncul dari hasil percobaan terdapat $\mathrm{k}$ hasil yang merupakan kejadian $\mathrm{A}$, maka peluang kejadian $\mathrm{A}$ atau $\mathrm{P}(\mathrm{A})$ ditentukan

$P(A)=\frac{k}{n}$

3. Kisaran nilai peluang

Misalkan A adalah sembarang kejadian pada ruang sampel $\mathrm{S}$ dengan $\quad \mathrm{n}(\mathrm{S})=\mathrm{n}, \quad \mathrm{n}(\mathrm{A})=\mathrm{k} \quad$ dan $\quad 0 \leq k \leq n \leftrightarrow 0 \leq \frac{k}{n} \leq$ 1 , maka $0 \leq P(A) \leq 1$. Jadi peluang kejadian terletak pada interval tertutup[0,1] Suatu kejadian yang peluang 0 dinamakan kejadian mustahil Suatu kejadian yang peluang 1 dinamakan kejadian pasti

4. Frekuensi harapan suatu kejadian

Jika $A$ adalah suatu kejadian pada ruang sampel sebagai $\mathrm{P}(\mathrm{A})$ maka frekuensi harapan kejadian $\mathrm{A}$ dan $\mathrm{n}$ kali percobaan $F h=n x P(A)$

5. Peluang komplemen suatu kejadian misal $s$ adalah ruang sampel dengan dengan $n(S)=n$. A adalah kejadian pada ruang sampel $\mathrm{s}$ dengan $\mathrm{n}(\mathrm{A})=\mathrm{k} \operatorname{dan} A^{c}$ adalah komplemen kejadian A maka 


$$
\begin{aligned}
& n\left(A^{c}\right)=n-k, \text { sehingga } P\left(A^{c}\right)=\frac{n-k}{n}=1-\frac{k}{n}=1-P(A) \\
& P(A)+P\left(A^{c}\right)=1
\end{aligned}
$$

\section{Metode}

Penelitian menggunakan penenlitian tindakan kelas (PTK). Ebbut dalam (Kasbolah, 2011, p.85) mendefinisikan penelitian tindakan merupakan studi yang sistematis yang dilakukan dalam upaya memperbaiki praktik-pratik dalam pendidikan dengan melakukan tindakan praktis secara refleksi dari tindakan tersebut. Ebbut melihat proses pelaksanaan penelitian tindakan ini sebagai suatu rangkaian siklus yang berkelanjutan. Dalam penelitian ini menggunakan 2 siklus yang masing-masing terdiri dari empat tahap yaitu perencanaan, pelaksanaan, pengamatan, evaluasi dan refleksi.

\section{Setting Penelitian}

Penelitian tindakan kalas ini dilaksanakan di SMA Negeri 5 Muaro-Jambi yang berlokasi di jalan Jambi-Suak kandis km 24 desa Arang-arang, pada mata pelajaran Matematika, dikelas XI IPA.2 yang siswanya berjumlah 19 orang yang terdiri dari 2 siswa laki-laki dan 17 siswa perempuan..

\section{Siklus Penelitian}

Dalam penelitian tindakan kelas ini, peneliti menggunakan 2 siklus, masing-masing siklus terdiri 4 tahap yaitu :

\section{Siklus pertama yang meliputi:}

\section{a. Tahap perencanaan}

Pada tahap ini, peneliti mempersiapkan media dan instrumen yang dipakai yaitu

1. Rencana pelaksanaan pembelajaran 
2. Media instrumen yaitu alat-alat yang digunakan pada kegiatan eksperimen

3. Lembar kerja siswa

4. Lembar pengamatan

5. Menyiapkan bahan evaluasi

\section{b. Tahap pelaksanaan}

Pada tahap ini dilakukan langkah-langkah pembelajaran, peneliti menggunakan metode eksperimen dengan model pembelajaran kooperatif,

1. Guru membagi siswa menjadi 4 kelompok dan masing-masing kelompok terdiri dari empat atau lima anggota.

2. Guru menyampaikan tujuan pembelajaran yaitu menentukan peluang kejadian dari suatu percobaan. dan Guru memberikan motivasi kepada siswa agar menggunakan kesempatan sebaikbaiknya dalam memperoleh pendidikan

3. Guru menyajikan impormasi tentang peluang

4. Guru membimbing kegiatan eksperimen kelompok siswa dalam bekerja

5. Siswa menyampaikan hasil diskusinya didepan kelas

6. Untuk hasil yang baik guru memberikan penghargaan.

\section{c. Tahap pengamatan dan evaluasi}

Untuk mengetahui keberhasilan pembelajaran perlu melakukan pengamatan terhadap siswa, apakah selama proses pembelajaran siswa aktif atau pasif. Apakah selama proses pembelajaran siswa menjadi meningkat minat belajarnya atau tidak, 
semua akan dicatat dalam lembar pengamatan dan akan menjadi data penting untuk tindakan berikutnya.

Dan untuk mengetahui tingkat keberhasilan kegiatan pembelajaran dilaksanakan evaluasi. Evaluasi digunakan untuk mengukur kwalitas proses pembelajaran dengan melakukan tes tulisan dengan jumlah soal sebanyak 10 butir.

\section{d. Tahap refleksi}

Pada tahap ini peneliti merefleksikan hasil pengamatan dan evaluasi tingkat ketercapaiannya baik yang terkait dengan proses pembelajaran maupun terhadap hasil tindakan.

Refleksi ini bertujuan untuk menemukan keunggulan keunggulan dan kelemahan-kelemahan atau hambatan-hambatan yang mengganjal, upaya dalam pencapaian tujuan secara optimal, dan untuk melakukan adaptasi terhadap strategi/pendekatan/metode/model pembelajaran yang diterapkan lebih memantapkan perencanaan dan langkah-langkah tindakan yang lebih spesifik dalam rangka pelaksanaan tindakkan selanjutnya, Jamal Ma'mur dan Asmani (2011).

\section{Siklus kedua menunggu refleksi siklus ke-1}

\section{Instrumen penelitian}

Untuk mendapatkan data yang valid dan akurat, peneliti menggunakan instrumen berupa :

1. Catatan yang meliputi " persiapan, pelaksanaan dan penelitian".

2. Lembar pengamatan siswa

3. Lembar evaluasi 


\section{Hasil}

\section{Refleksi awal}

Gambaran awal penulis mengadakan freetest dalam bentuk esay tentang titik sampel dan ruang sampel. Dari 19 orang siswa hasil tes yang dilakukan penulis didapatkan data nilai 11 orang siswa yang masih dibawah KKM ( untuk matematika SMA N 5 Muaro Jambi) berarti siswa masih kesulitan didalam belajar.

\section{Siklus Pertama}

\section{Perencanaan:}

Mempersiapkan

1. Media eksperimen (uang logam Rp 100, dadu)

2. Lembar kerja siswa ( LKS)

3. Lembar pengamatan

4. Rencana pelaksanaan pembelajaran(RPP)

\section{Pelaksanaan:}

Waktu yang disediakan 4 x 45 menit yaitu 2 kali pertemuan. 20 menit pertama pelaksanaan tindakan dimulai dengan pembelajaran tentang titik sampel dan ruang sampel dimulai dari indikator yang harus dikuasai siswa.

Guru mengamati kerja kelompok siswa dengan menggunakan format lembar pengamatan siswa serta memberikan. Pada pertemuan selanjutnya dilakukan tes dan pengisian angket format penilaian minat siswa.

\section{Pengamatan dan evaluasi:}

Hasil tes siswa diatas KKM berarti tuntas, tetapi masih banyak nilainya berdekatan dengan KKM artinya pembelajaran 
belum optimal, dari hasil observasi diketahui guru menyampaikan materi terlalu cepat dan terfokus pada guru, dimana siswa hanya menerima pelajaran dan pada melakukan kegiatan percobaan hanya sebagian siswa yang aktif melaksanakan dalam tiap kelompoknya, sehingga kurang terjalinnya kerja sama antar siswa dalam kelompoknya dalam proses kegiatan pembelajaran.

\section{Refleksi :}

Melihat hasil obsrevasi, guru berusaha memperbaiki pada siklus ke-2 dengan jalan menurunkan sedikit tempo penyajian pelajaran, dan diberikan kesempatan pada siswa untuk bertanya tentang materi yang akan dilaksanakan percobaan.

\section{Siklus kedua}

\section{Perencanaan:}

Mempersiapkan pertanyaan-pertanyaan yang mampu membangun konsep, menurunkan tempo penyajian materi yang disajikan tentang peluang suatu kejadian, pembelajaran direncanakan satu minggu sesui jadwal pelajaran yaitu 2 x 45 menit dan 2 x 45 menit.

\section{Pelaksanaan :}

20 menit pertama pelaksanaan tindakan dimulai guru mengingatkan kembali tentang materi sebelumnya dan dilanjutkan menjelaskan pembelajaran tentang peluang suatu kejadian dari suatu percobaan. Kemudian 45 menit berikutnya siswa diminta untuk mengerjakan LKS secara berkelompok dengan media yang disediakan. Sisa waktu 35 menit diminta salah satu kelompok mempresentasikan hasil kerja kelompok. Dan diberikan kesempatan 
siswa untuk bertanya terhadap masalah-masalah yang dihadapai pada saat melakukan kegiatan percobaan, dan bagi siswa yang memperoleh hasil yang memuaskan diberikan aplus. Guru bersama siswa membuat kesimpulan.

\section{Pengamatan dan evaluasi}

Hasil tes siswa sangat menyakinkan rata-rata nilai anak naik dibandingkan siklus ke-1, siswa menginginkan kalau bisa dalam pelajaran matematika yang dapat digunakan media maka gunakanlah, kemudian dalam mengerjakan soal-soal matematika sebaiknya dilaksanakan dengan kerja kelompok, menyebabkan banyak kesempatan siswa untuk berinteraksi dengan siswa lain, sehingga siswa yang belum memahami dapat bertanya kepada siswa yang lebih paham. Dari hasil pengamatan diketahui semangat siswa belajar meningkat dan kemauan mengemukakan pendapat juga meningkat.

\section{Refleksi}

Secara keseluruhan hasil pembelajaran ini sudah memenuhi harapan yakni adanya peningkatan minat dan hasil belajar. Siswa menjadi lebih aktif dan berpartisipasi yang tinggi dalam pelaksanaan pembelajaran. Hal ini terlihat dari tabel 1 menunjukkan hasil refleksi belajar peluang dengan jumlah siswa 19 orang dan KKM 77, dan tabel 2 menunjukkan hasil angket penggunaan media belajar. 
Tabel 1.

Refleksi belajar topik peluang siklus I dan II

\begin{tabular}{|l|l|l|l|}
\hline Nilai anak & $\begin{array}{l}\text { Refleksi awal } \\
\text { (Konfensional) }\end{array}$ & Siklus 1 & Siklus 2 \\
\hline Jumlah nilai dibawah KKM & 11 & 3 & 0 \\
\hline Prossentase ketuntasan & $42,10 \%$ & $84,21 \%$ & $100 \%$ \\
\hline Rata- nilai kognitif & 65,23 & 77.84 & 82.89 \\
\hline
\end{tabular}

\section{Pembahasan}

Sebelum peneliti melakukan tindakan dalam meningkatkan hasil belajar dan minat siswa terkait materi peluang terlihat bahwa siswa kelas X IPA 2 SMAN 5 Muaro Jambi masih bnayak yang memperoleh nilai di bawah KKM yaitu 11 siswa sehingga persentase ketuntasan belajar matematika hanya mencapai $42.10 \%$. Namun, pada saat penulis melakukan tindakan dengan menggunakan media eksperimen berupa dadu dan mata uang logam seratus rupiah terjadi peningkatan persentase ketuntasan sebesar 84, $21 \%$. Persentase ketuntasan tersebut menurut penulis dapat ditingkatkan dengan memperbaiki penyampaian atau instruksi pembelajaran, dan memperhatikan siswa lebih intens. Sehingga, pada siklus kedua pencapaian ketuntasan belajar meningkat menjadi $100 \%$, meskipun tingkat pencapaian kognitif siswa hanya $82.89 \%$.

Berkenaan dengan tujuan penelitian, yaitu meningkatkan hasil belajar siswa dengan menggunakan media eksperimen berupa dadu dan uang logam, ketuntasan belajar siswa pada siklus kedua 
meningkat secara signifikan dan siswa dapat menyelesaikan soalsoal peluang secara sempurna dilihat dari persentase kognitif siswa sebesar $82,89 \%$ yang memiliki makna bahwa siswa memperoleh hasil belajar dengan rata-rata 80 .

\section{Kesimpulan}

Berdasarkan hasil dan pembahasan diatas maka dapat disimpulkan sebagai berikut:

1. Pembelajaran matematika dengan menggunakan metode eksperimen dengan model pembelajaran kooperatif dapat meningkatkan minat belajar siswa

2. Pembelajaran matematika dengan menggunakan metode eksperimen dengan model pembelajaran kooperatif dapat meningkatkan pemahaman siswa terhadap matematika khususnya materi peluang suatu kejadian dan dapat meningkatkan hasil belajar siswa. 


\section{Daftar Rujukan}

Efendi.1995. Filsafat komunikasi. Bandung. Remaja Rosdakarya.

Jamal Ma'mur Asmani. 2011. Tips Pintar PTK :Penelitian Tindakan kelas. Jogjakarta: Laksana

Al.Krismanto. 2003. Beberapa Teknik Moddel, dan Strategi dalam Pembelajaran Matematika. Yogyakarta: Departemen Pendidikan Nasional. Pusat pengembangan penataran guru (PPPG) matematika.

Kasiani, kasbolah E.S. 2001. Penelitian tidakan kelas. Malang: Universitas Negeri Malang.

Wiryamin. 1989. Psikologi Pendidikan. Semarang: Toha Putra.

Karti Soeharto, dkk. 1995. Teknologi Pembelajaran. Surabaya:SIC.

Wahyudin Djumanta, R. Sudrajat. 2008. Mahir Mengembangkan Kemampuan Matematika. Jakarta: Aneka Ilmu.

Rosihan Ari Y, Indriyastuti. 2008. Prespektif Matematika 2 untuk kelas XI SMA dan MA program IPA. Solo: Platinum.

Husein Tampomas.1999. Seribu Pena Matematika SMU kelas 2. Bogor: Erlangga.

Tri Dewi Listya, Herawati, Endang Daiman D. 2000. Matematika $2 A$ untuk kelas 2 SMU. Jakarta: Yudhistira. 